José Florencio F. Lapeña, Jr., MA, MD

\section{Department of Otorhinolaryngology} College of Medicine, University of the Philippines Manila, Philippines

\section{Department of Otorhinolaryngology} Head and Neck Surgery

East Avenue Medical Center, Diliman

Quezon City, Philippines

Correspondence: Prof. Dr. José Florencio F. Lapeña, Jr. Department of Otorhinolaryngology

Ward 10, Philippine General Hospital

Taft Avenue, Ermita, Manila 1000

Philippines

Phone: (632) 5548467

Telefax: (632) 5244455

Email: lapenajf@upm.edu.ph

The author declared that this represents original material that is not being considered for publication or has not been published or accepted for publication elsewhere, in full or in part, in print or electronic media; that the manuscript has been read and approved by the author, that the requirements for authorship have been met by the author, and that the author believes that the manuscript represents honest work.

\title{
The Physician's Pledge: Promises at Dawn, Passages in Darkness
}

\author{
"Do not go gentle into that good night."1 \\ - Dylan Thomas
}

The old guards are fading as we take their place. Many of us are ourselves in golden years, with more of our lives behind than before us. But all around us, many lives much younger than ours are being violently and unjustly terminated on a daily basis. In our very homes and communities, "man's inhumanity to man makes countless thousands mourn." ${ }^{2}$ As the morning of our life slowly fades and twilight shadows lengthen, this realization should stir us to "rage against the dying of the light"1 - not so much for ourselves, but on behalf of these countless thousands.

Whether we accomplished little, or much in our lifetime, the promises we once made will ultimately be measured against our own passage. Many of these pledges were uttered in our springtime, when dawn was breaking on our seemingly endless day. Over our lifetime, we may have kept some oaths, and broken others-in matters large or small. Many of these are personal matters that do not involve the rest of us. But there is one vow that we professed in common, and that concerns all of us-- the Physician's Oath. ${ }^{3}$

At the time of being admitted as a member of the medical profession:

I SOLEMNLY PLEDGE to consecrate my life to the service of humanity;

I WILL GIVE to my teachers the respect and gratitude that is their due;

I WILL PRACTISE my profession with conscience and dignity;

THE HEALTH OF MY PATIENT will be my first consideration;

I WILL RESPECT the secrets that are confided in me, even after the patient has died;

I WILL MAINTAIN by all the means in my power, the honour and the noble traditions of the medical profession;
MY COLLEAGUES will be my sisters and brothers;

I WILL NOT PERMIT considerations of age, disease or disability, creed, ethnic origin, gender, nationality, political affiliation, race, sexual orientation, social standing or any other factor to intervene between my duty and my patient;

I WILL MAINTAIN the utmost respect for human life;

I WILL NOT USE my medical knowledge to violate human rights and civil liberties, even under threat;

IMAKE THESE PROMISES solemnly, freely and upon my honour. 
The promises we made in this oath now confront us with urgency and timeliness. How much longer can we turn a blind eye or a deaf ear when scores are slaughtered daily? How much longer shall we remain silent? Is omission less evil than commission? The Honorable Mariott Brosius of Lancaster, Pennsylvania on "The Medical Profession and the State" reminds us: ${ }^{4}$

He should not be lulled to repose by the delusion that he does no harm who takes no part in public affairs. He should know that bad men need no better opportunity than when good men look on and do nothing. He should stand to his principles even if leaders go wrong.

Darkness is creeping upon us, and we too must pass on. In the deafening silence, the song rings in our ears: "in the evening of my life I shall look to the sunset, at a moment in my life when the night is due. And the question I shall ask only I can answer. Was I brave and strong and true?"5 It is not too late to "conduct a pre-mortem on your life" to answer this question, unless you "would rather wait until someone else conducts the post-mortem on you."

We have solemnly pledged "to consecrate" our lives "to the service of humanity," and "maintain the utmost respect for human life."3 Our patients are our brethren whose "health" - wellness and wholeness - should be our "first consideration." We promised that we "WILL NOT PERMIT considerations of age, disease or disability, creed, ethnic origin, gender, nationality, political affiliation, race, sexual orientation, social standing or any other factor to intervene between (our) duty and (our) patient." ${ }^{\prime 3}$ We must not break this promise.

"The woods are lovely, dark and deep, But I have promises to keep,

And miles to go before I sleep, And miles to go before I sleep."

- Robert Frost

REFERENCES

1. Thomas DM. "Do not go gentle into that good night" In Country Sleep and Other Poems. New York: New Directions, 1952. P. 18.

2. Burns R. "Man was made to mourn: A dirge" In The Poems and Songs of Robert Burns. Eliot CW (Editor). The Harvard Classics Volume 6. New York: P.F. Collier \& Son, 1909-14; Bartleby.com 2001. [cited 29 October 2016.] Available at: http://www.bartleby.com/6/54.html.

3. The World Medical Association Declaration of Geneva. Adopted by the $2^{\text {nd }}$ General Assembly of the World Medical Association, Geneva, Switzerland, September 1948; Amended by the $22^{\text {nd }}$ World Medical Assembly, Sydney, Australia, August 1968, the $35^{\text {th }}$ World Medical Assembly, Venice, Italy, October 1983 and the $46^{\text {th }}$ WMA General Assembly, Stockholm, Sweden, September 1994; Editorially revised by the $170^{\text {th }}$ Council Session, Divonne-les-Bains, France, May 2005 and the $173^{\text {rd }}$ Council Session, Divonne-les-Bains, France, May 2006. [Cited 29 October 2016.] Available from: http://www.wma.net/en/30publications/10policies/g1/.

4. Brosius M. The Medical Profession and the State [Alumni Oration]. The Medical Bulletin: A Monthly Journal of Medicine and Surgery. 1895 June;17:201-203. [Cited 29 October 2016.] Available from: http://quoteinvestigator.com/2010/12/04/good-men-do/\#note-1664-6.

5. Bricusse L (Music), Rattigan T (Lyrics). "Fill the World With Love". From the Musical "Goodbye, Mr. Chips" Peter O'Toole, Petula Clark (Original Artists). Metro-Goldwyn-Mayer, 1969.

6. Lapeña JF. From here and now to infinity and eternity: A message to new medical doctors. Mens Sana Monogr. 2014 Jan-Dec; 12(1):153-160. DOI: 10.4103/0973-1229.130328 PMCID: PMC4037894 PMID: 24891804.

7. Frost R. "Stopping by woods on a snowy evening" from The Poetry of Robert Frost. Lathem EC (Editor) @1923, @ 1969 Henry Holt and Company, Inc., renewed 1951, by Robert Frost. [Cited 29 October 2016.] Available from: https://www.poetryfoundation.org/poems-and-poets/poems/ detail/42891. 